\section{Article}

Doi 10.5943/mycosphere/6/5/4
ISSN 20777019

Mycosphere

Online Edition

\title{
Mycosphere Essays 1: Taxonomic Confusion in the Ganoderma lucidum Species Complex
}

\section{Hapuarachchi KK ${ }^{1,2,3}$, Wen $\mathrm{TC}^{1}$, Deng $\mathrm{CY}^{5}$, Kang $\mathrm{JC}^{1}$ and Hyde $\mathrm{KD}^{2,3,4}$}

\author{
${ }^{I}$ The Engineering and Research Center of Southwest Bio-Pharmaceutical Resource Ministry of Education, Guizhou \\ University, Guiyang 550025, Guizhou Province, China \\ ${ }^{2}$ Key Laboratory for Plant Diversity and Biogeography of East Asia, Kunming Institute of Botany, Chinese Academy of \\ Sciences, 132 Lanhei Road, Kunming 650201, China \\ ${ }^{3}$ Center of Excellence in Fungal Research, and ${ }^{4}$ School of Science, Mae Fah Luang University, Chiang Rai 57100, \\ Thailand \\ ${ }^{5}$ Guizhou Academy of Sciences, Guiyang, 550009, Guizhou Province, China
}

Hapuarachchi KK, Wen TC, Deng CY, Kang JC, Hyde KD - Mycosphere Essays 1: Taxonomic confusion in the Ganoderma lucidum species complex. Mycosphere 6(5), 542-559, Doi 10.5943/mycosphere/6/5/4

\begin{abstract}
The genus Ganoderma (Ganodermataceae) has been widely used as traditional medicines for centuries in Asia, especially in China, Korea and Japan. Its species are widely researched, because of their highly prized medicinal value, since they contain many chemical constituents with potential nutritional and therapeutic values. Ganoderma lucidum (Lingzhi) is one of the most sought after species within the genus, since it is believed to have considerable therapeutic properties. In the G. lucidum species complex, there is much taxonomic confusion concerning the status of species, whose identification and circumscriptions are unclear because of their wide spectrum of morphological variability. In this paper we provide a history of the development of the taxonomic status of the G. lucidum species complex. We present a phylogeny for the G. lucidum complex based on multigene analysis with combined 5.8S-ITS rDNA, RPB1, and EF-1 $\alpha$ sequence data for 17 taxa of the complex. The taxonomic standing of these species is briefly discussed. Further clarification is, however, required. Type specimens, epitypes, reference collections, fresh collections and vouchered multigene nucleotide sequence data of more informative DNA markers should be used to determine the taxonomy of species in the G. lucidum complex.
\end{abstract}

Key words - Ganoderma lucidum complex - Lingzhi - morphology - phylogenetic analyses taxonomic status

\section{Introduction}

The genus Ganoderma was established by Karsten (1881) with Ganoderma lucidum (W. Curt, Fries.) as the only species. Donk (1948) introduced Ganodermataceae with the laccate and stipitate white rot fungus Polyporus lucidus W. Curtis as its type species (Moncalvo \& Ryvarden 1997) and placed the family in Polyporales, Basidiomycotina (Schwarze \& Ferner 2003). Ganoderma is a cosmopolitan genus (Cao \& Yuan 2013). Ganoderma species have a worldwide distribution in green ecosystems both in tropical and temperate geographical regions. They are usually found in subtropical and tropical regions since they can survive under hot and humid 
conditions (Pilotti et al. 2004). Ganoderma species grow as a facultative parasite that can live as saprobes on rotting stumps and roots (Pilotti et al. 2004). Basidiocarps, the sexual structures in Ganoderma, grow from a living, or more commonly, from a dead trunk or branch of a tree in the form of a bracket. One of the two types of basidiocarps is produced, depending on the species: a laccate fruiting body with a shiny upper surface, or a non - laccate fruiting body with a dull upper surface (Smith \& Sivasithamparam 2000a, Pilotti et al. 2004).

Ganoderma species have important economic value due to their medicinal properties and pathogenicity (Dai et al. 2007a, Dai et al. 2009). Ganoderma species cause white rot of hard woods by decomposing lignin, cellulose and related polysaccharides (Hepting 1971, Adaskaveg et al. 1991). The root and stem rots caused by Ganoderma species, results in loss in forestry yields [e.g. Elaeis guineensis (oil palm), Glen et al. 2009)] and other important trees [e.g. Hevea brasiliensis (rubber) worldwide (Monkai et al. 2014)]. Ganoderma is a mushroom used as a traditional medicine in Asia and is called "Ling Zhi", Chi-zhi" or"Rui-zhi" in China, "Reishi", "Munnertake" or "Sachitake" in Japan and "Youngzhi" in Korea (Wagner et al. 2003, Paterson 2006). Species of Ganoderma have been reported to contain chemical constituents such as polysaccharides, proteins, amino acids, fatty acids, terpenoids, steroids, alkaloids, and phenolic compounds, with potential nutritional and therapeutic values (Boh et al. 2007, Mizuno 1995, Paterson 2006, Singh et al. 2013). These bioactive constituents are reported to be responsible for anti-inflammatory, anti-tumor, antioxidant, immunomodulatory, anti-diabetic, anti-viral, anti-bacterial, and anti-fungal properties of the mushroom (Paterson 2006, Cao et al. 2013, De Silva et al. 2012a, b, De Silva et al. 2013). Hence, the fruiting bodies of Ganoderma species have gained wide popular use as dietary supplements in China, Japan, North America and the other regions of the world. Ganoderma has been used as a functional food to prevent and treat immunological diseases, such as hypertension, tumorigenesis, insomnia, diabetes, migraine, as well as arthritis, bronchitis, asthma, anorexia, gastritis, hemorrhoids, hypercholesterolemia, nephritis, dysmenorrhea, constipation, lupus erythematosis, hepatitis, and cardiovascular problems (Liu et al. 2002, Paterson 2006, Wang et al. 2012). Ganoderma products come in the form of coffee, powder, tea, dietary supplements, spore products, drinks, syrups, tooth pastes, soaps and lotions and have been commercialized as effective food and drug supplements (Figure 1) for health benefits (Chang \& Buswell 1999, Lai et al. 2004, Singh et al. 2013).

There are 430 epithets listed in Index Fungorum (2015) for Ganoderma, while Kirk et al. (2008) estimates there are 80 species. The taxonomic situation within Ganoderma is unclear as the species and genus concepts are confused because similar fungi are found in Fomes (Fr.) Fr 1849, Polyporus P. Micheli 1729 and Tomophagus Murril 1905 (Paterson 2006). Richter et al. (2014) suggested using a combination of morphological, chemotaxonomic and molecular methods to develop a more stable taxonomy for the genus. For over a century, the highly prized medicinal fungus, known as "Lingzhi" in East Asia, has been assigned to Ganoderma lucidum, a species originally described from Europe (Cao et al. 2012). William Curtis described and illustrated this taxon as Boletus lucidus in (1781) and Karsten's Fungi Fenniae Exsiccati (1865) contained a specimen under the name $P$. lucidus with rough basidiospores (Adaskaveg \& Gilbertson 1986). Ganoderma lucidum was described by Curtis (1871) based on material from Peckham, London, UK and the epithet was sanctioned by Fries (1821).

Adaskaveg \& Gilbertson (1986) sugessted Karsten (1881) has mistakenly attributed the epithet lucidum to Von Leysser, and this error has been established in numerous publications throughout history. Ganoderma lucidum sensu lato has been reported from East Asia (China, Japan and South Korea), East Africa (Ghana, Kenya and Tanzania) as well as Europe (almost all the European countries), North America (Canada and U.S.A.), Oceania (Australia), South America (Argentina, Brazil and Uruguay), South and Southeast Asia (India, Indonesia, Philippines, Thailand and Vietnam). However, the collections named as G. lucidum from different parts of the world are scattered in several separated lineages in phylogenetic analyses of the genus (Wang et al. 2012).

As early as 800 years ago in the Yuan Dynasty (A.D. 1280 - 1368), Ganoderma lucidum has been represented in paintings, carvings, furniture, carpet design, jewelry, perfumes and many more 
creative artworks (Wasser \& Weis 1999a). Anon (1955) stated, that the G. lucidum species complex have been used as Traditional Chinese Medicine for over two millennia (Zhou et al. 2014). This species viewed as 'herb of spiritual potency' or 'mushroom of immortality', and symbolizes sanctity, success, goodness and longevity (Gao \& Zhou 2003, Wasser 2005, Lin 2009, De Silva et al. 2012). Ganoderma lucidum has been widely used for naming the commercialized "Lingzhi" products in the world market of the mushroom industry, since it has health benefits (Lai et al. 2004). The annual sale of products derived from G. lucidum is estimated to be more than US\$ 2.5 billion in Asian countries, including China, Japan, and South Korea (Li et al. 2013).

In the mid-nineties of the $20^{\text {th }}$ century, molecular phylogenetic analyses indicated that collections named as G. lucidum in East Asia were in most cases not conspecific with G. lucidum from Europe (Yang \& Feng 2013). The taxonomy of the G. lucidum complex has long been subject to debate and even after many years of discussions, the taxonomy of the G. lucidum complex remains still problematic. The main purpose of this paper is to identify the taxonomic problems in the G. lucidum species complex. In this study, the phylogeny of the G. lucidum complex was examined by analysis of 5.8S-ITS rDNA, RPB1, and EF-1 $\alpha$ sequence data representing species from Asia, Europe and North America to clarify the phylogenetic relationships within this complex.

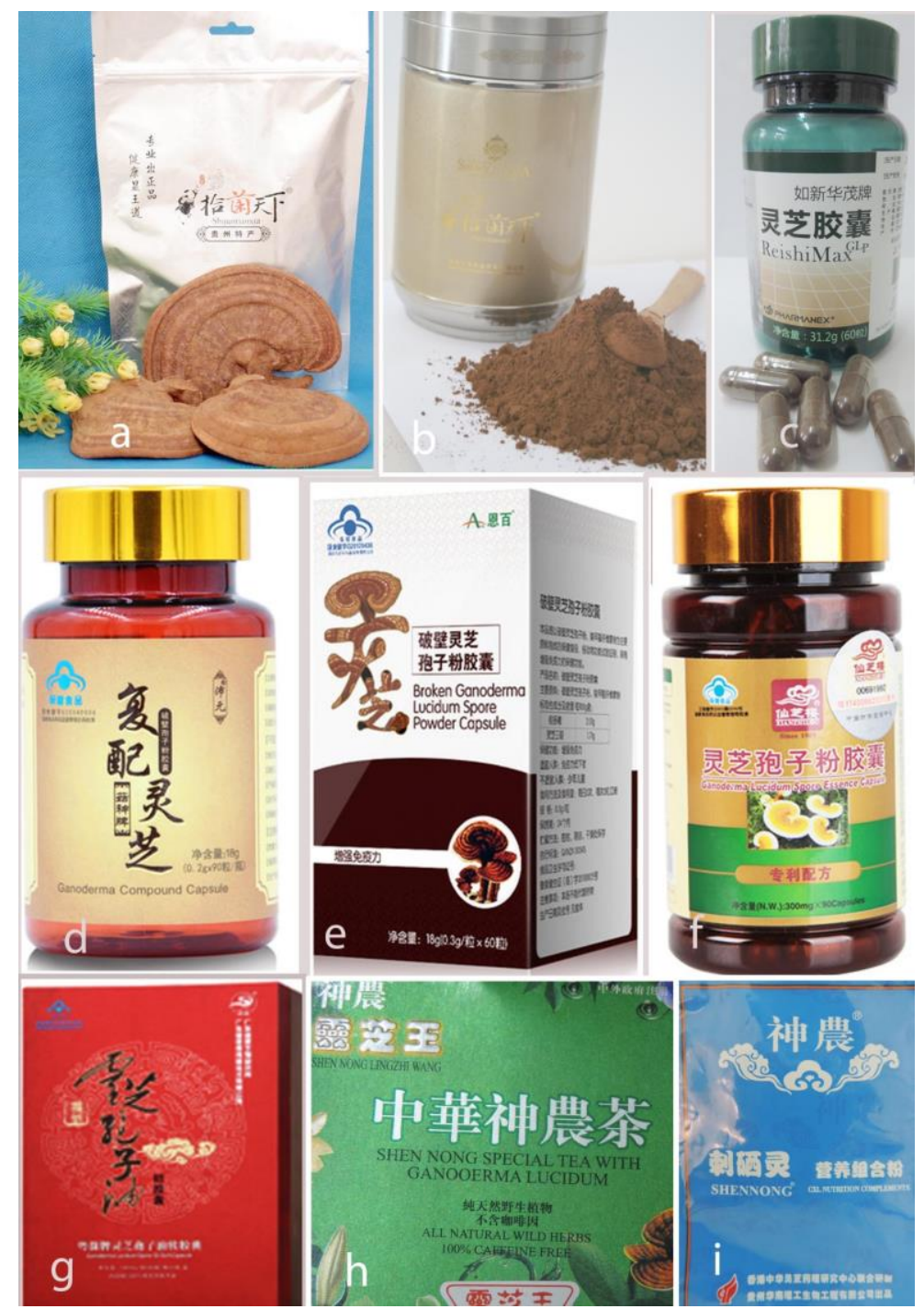

Fig. 1 - Ganoderma products use as drug supplements and food. a. Ganoderma fruit body. b. Ganoderma spore powder. c. Ganoderma spore powder capsules. d. Ganoderma compound capsules. e. Broken Ganoderma lucidum spore powder capsules. f. Ganoderma spore essence capsules. g. Ganoderma spore oil. h. Ganoderma lucidum tea, i. Se enriched Ganoderma nutrition complements. 


\section{History of Ganoderma taxonomy}

Traditional Chinese books classified Ganoderma into six species with reference to the colour of the fruit body: Sekishi is red, Shishi violet - like, Kokushi black, Oushi yellow, Hakushi white and Seishi blue and assigned based on different triterpenoid patterns (Szedlay 2002). Ganodermataceae contains five genera: Ganoderma P. Karst 1881, Amauroderma Murril 1905, Haddowia Steyaert 1972, Humphreya Steyaert 1972 and Polyporopsis Audet 2010 (Richter et al. 2014). Patouillard (1889) listed 48 species of Ganoderma worldwide (Adaskaveg \& Gilbertson 1986). Ganoderma includes the subgenus Ganoderma that includes Sect. Ganoderma and Sect. Phaenema, subgenus Eflvingia and subgenus Trachyderma (Zhao \& Zhang, 2000). Trachyderma Imazeki 1952 is illegitimate because there is a lichenised genus called Trachyderma Norman 1853 which is considered as a synonym of Ganoderma (Richter et al. 2014). The traditional taxonomy of Ganoderma is based on its morphological traits and this genus was divided into two distinct groups, the laccate ( $G$. lucidum complex) and the non-laccate ( $G$. applanatum complex) species, which refer to the subgenera Ganoderma and Elfvingia respectively (Zheng et al. 2007).

\section{Unique morphological features of Ganoderma}

The double walled basidiospores with interwall pillars are a key diagnostic feature for the genus (Smith \& Sivasithamparam 2000a). Ganoderma species have the following characteristics: Basidiomes annual or perennial, stipitate to sessile, pileus surface with a thick, dull cuticle or shiny and laccate with a thin cuticle or cuticle of clavate end cells, context cream coloured to dark purplish brown, soft and spongy to firm-fibrous, pore surface cream coloured, bruising brown, the pores regular, 4-7 per mm, tube layers single or stratified, pale to purplish brown, stipe when present central or lateral, hyphal system dimitic, generative hyphae with clamps, skeletal hyphae hyaline to brown, non-septate, often with long, tapering branches, basidia broadly ellipsoid, tapering abruptly at the base, cystidia absent, basidiospores broadly to narrowly ellipsoid with a truncate apex and apical germ pore, wall two-layered, the endosporium brown and separated from the hyaline exosporium by inter-wall pillars, negative in Melzer's reagent, 7-30 $\mu \mathrm{m}$ long (Ryvarden 2004).

\section{Why Ganoderma has a confused nomenclature?}

Ganoderma species identification and circumscriptions have often been unclear and taxonomic segregation of the genus has been controversial (Moncalvo et al. 1995). A number of Ganoderma collections and species have been misnamed. This is because the presence of heterogenic forms, taxonomic obstacles and inconsistencies in the way the genus has been subdivided (Mueller et al. 2007). Since Ganoderma species are genetically heterogeneous, a wide range of genetic variation has been reported and caused by out crossing over generations and different geographical origins (Miller et al. 1999, Pilotti et al. 2003). This has led to variation in their listed morphological characteristics, even within same species (Hong et al. 2001). Environmental factors, variability, inter hybridization and individual morphological bias, mean identification of Ganoderma species is difficult (Zheng et al. 2007). Naming a species within this genus is confused and traditional taxonomic methods based on morphology are inconclusive for establishing a stable classification system for Ganoderma species (Hseu et al. 1996, Hong et al. 2002). Hence an uncertain nomenclature has resulted. This confusing situation is mainly the result of different authors using various criteria during identification. Some authors strictly only focus on host-specificity, geographical distribution and macro morphology of basidiomes, while other authors only focus on spore characters as the primarily taxonomic characters (Sun et al. 2006 , Ekandjo 2012).

\section{Ganoderma lucidum species complex}

Ganoderma lucidum sensu lato is a species complex. The taxonomy of this complex has long been the subject of debate, and different opinions have been raised regarding the validity of its members. The G. lucidum species complex includes 12 taxa (Table 2). These species are accepted as members of the G. lucidum species complex. In East Africa, Ryvarden and Johansen (1980) 
parsimoniously treated all names of the G. lucidum complex as the 'G. lucidum group', because of the lack of a morphological solution to name species in this complex.

\section{Ganoderma lucidum in China}

Patouillard (1907) reported G. lucidum from China and later on Teng (1934) accounted more collections of G. lucidum from different regions (Wang et al. 2012). Liu (1974) compiled a monograph of Traditional Chinese Medicinal fungi, and he assigned G. lucidum to "Lingzhi" in his book. Since then, G. lucidum was accepted as the scientific binomial of "Lingzhi" in many reports on Chinese edible and medicinal mushrooms (Ying et al. 1987, Mao 1998, Dai et al. 2009, Cao 2012). Several species morphologically similar to G. lucidum have also been described from all over the world, including G. multipileum D. Hou (Hou 1950), G. sichuanense J.D. Zhao and X.Q. Zhang (Zhao et al. 1983) and G. lingzhi (Cao et al. 2012) from China, G. resinaceum Boud (Patouillard 1889) from Europe, and Ganoderma Murrill, G. sessile Murrill, G. tsugae Murrill and G. zonatum Murrill (Murrill 1902, 1908) from USA (Cao et al. 2012, Zhou et al. 2014).

Studies of Moncalvo et al. (1995) highlighted that G. lucidum sensu stricto was distributed in northern and southern Europe, and probably extended to China. Further he found, the species named G. lucidum from both Europe and mainland China was not conspecific based on analyses of ITS and 25S ribosomal DNA sequences (Moncalvo et al. 1995a). Later, some authors (Moncalvo et al. 1995a, Pegler \& Yao 1996, Hong \& Jung 2004) have confirmed this idea, but misapplication of this name yet to be correct. Later, it was found that G. lucidum, distributed in tropical Asia is $G$. multipileum Ding Hou, which is not conspecific with the G. lucidumsensu stricto distributed in Europe, even not conspecific with the real "Lingzhi" distributed in East Asia (Wang et al. 2009b). Wang et al. (2012) further stated that the misapplication of G. lucidum to the Chinese species has a very short history, although it has become dominant in the last few decades because the successful cultivation and medicinal value of the species. Meanwhile, the distribution of genuine G. lucidum in China was also confirmed by Cao et al. (2012) and Yang \& Feng (2013). Wang et al. (2012) proposed the name 'G. lucidum' as used for the Chinese species is erroneous and should be corrected and used as G. sichuanense. However, G. lucidum is incorrectly recorded in China, and around the world (Wang et al. 2012).

\section{Mystification of "lingzhi" in China}

The Chinese "lingzhi" has continuously been referred to the name G. lucidum in monographic works on Ganodermataceae in China. At first, Moncalvo et al. (1995) suggested the widely used medicinal species G. lucidum is a different species. Hawksworth (2005) proposed to conserve the name G. lucidum to an Asian type and introduce a new name for the European species (Yang \& Feng 2013). Later, Cao et al. (2012) named the medicinal species G. lucidum as G. lingzhi. Among the Chinese Ganoderma species, G. flexipes Pat, G. multipileum D. Hou, G. sichuanense J.D. Zhao and X.Q. Zhang, G. tropicum (Jungh.) Bres. and G. tsugae Murrill are the most similar species to G. lingzhi (Cao et al. 2012).

\section{Ganoderma lucidum in North America}

Overholts (1953) identified four North American species in the G. lucidum group and placed them in the Friesian genus Polyporus instead of Ganoderma and further he recognized Polyporus. lucidus and P. tsugae as a distinct species in North America. Overholts (1953) taxonomy was based on geographical distribution, host-specificity, macroscopic morphology and spore charateristics (Adaskaveg \& Gilbertson 1986). Both Overholts (1953) and Steyaert (1972) considerd Ganoderma sessile, G. polychromum, G. zonatum and G. sulcatum as synonyms or varities of $P$. lucidus (Moncalvo \& Ryvarden 1997). Moncalvo et al. (1995) proposed that G. boninense might be the correct name of the American specimens labeled as G. lucidum. Later Zhou et al. (2014) has clearly distinguished $G$. boninense, from $G$. sessile and $G$. tsugae, both which have been wrongly considered by several authors (Haddow 1931, Overholts 1953, Steyaert 1978) to be the American 
G. lucidum. The species originally described from the USA critically need to researched, because most of these species are old and were never subjected to phylogenetic analysis (Zhou et al. 2014).

\section{Unique morphological characteristics of Ganoderma lucidum}

The species Ganoderma lucidum itself is believed to grow only on hardwoods (Szedlay 1996). The basidiocarp is stipitate, with a pileus more or less imbricate. The surface of the pileus is covered with a dark red laccate layer, in the case of young fruit bodies with a non-laccate yellow to white margin. Basidiospores are ovate with a truncate apex. The basidiospores have numerous, narrow inter-wall pillars and "smooth" walls. The pilocystidia are medium long, clavate, amyloid, thick-walled, with abruptly tapering shafts (occasionally branched) intermixed with branching non-swollen hyphae in the mature pilear surface tissue (Szedlay 1996). The hyphal system is trimitic. Different authors describe different spore sizes. The Chinese G. lucidum has deeper coloured context (cream to buff, even darker near tube layer), a shorter cutis elements $(20-40 \times 7$ $-15 \mu \mathrm{m}$ ) (Wang et al. 2012). The European G. lucidum has slightly smaller basidiospores $7-12 \times$ $6-8 \mu \mathrm{m}$ (Paterson 2006). The African specimens of G. lucidum were considered to match the description of G. lucidum strains from Europe, also with smaller basidiospores $7-12 \times 6-8 \mu \mathrm{m}$ (Ryvarden \& Johansen 1980). Different articles have therefore used the same name for different taxa.

Table 1 Different spore sizes of Ganoderma lucidum

\begin{tabular}{lll}
\hline Author & Year & Basidiospore size $(\boldsymbol{\mu m})$ \\
\hline Pegler \& Yong & 1973 & $9-13 \times 6-8$ \\
Adaskaveg \& Gilbertson & 1986 & $10.6-(11.5)-11.8 \times 6.8-(7.4)-7.8$ \\
Wang \& Hua & 1991 & $7-12 \times 6-8$ \\
Wang et al & 2012 & $9-11.5 \times 6-8$ and $6.5-8.56 \times 5-6.5$ \\
\hline
\end{tabular}

Smith \& Sivasithamparam (2003) proposed a new species, G. steyaertanum B.J. Smith \& K. Sivasithamparam, to replace the mistakenly named G. lucidum in Australia and Indonesia which was named as G. lucidum by Cooke (1883, 1884, 1892), McAlpine (1895), Blackford (1944), and Smith \& Sivasithamparam (2003). It has a larger basidiospores $(7.3-12.7 \times 5-9.5 \mu \mathrm{m})$ than $G$. lucidum sensu stricto, pale yellow to grayish orange pores and small cutis cells $(20-27 \times 4.5-9.9$ $\mu \mathrm{m}$, (Smith \& Sivasithamparam 2003).

Table 2 Taxa belong to G. lucidum complex.

\begin{tabular}{ll}
\hline Taxa & References \\
\hline Ganoderma tsugae Murr. & Murril 1902 \\
Ganoderma valesiacum Boud. & Murril 1908 \\
Ganoderma oregonense Murr. & Murril 1908 \\
Ganoderma resinaceum Boud. & Patouillard 1889 \\
Ganoderma pfeifferi Bres. & Bazzalo \& Wright 1982 \\
Ganoderma oerstedii (Fr.) Torr. & Adaskaveg \& Gilbertson 1986 \\
Ganoderma ahmadii Stey. & Steyaert 1972 \\
Ganoderma multipileum D. Hou. & Hou 1950 \\
Ganoderma sichuanense J.D. Zhao \& X.Q. Zhang. & Zhao et al. 1983 \\
Ganoderma lingzhi Wu et al. & Cao et al. 2012 \\
Ganoderma sessile Murrill. & Murril 1902 \\
Ganoderma zonatum Murrill. & Murril 1902 \\
\hline
\end{tabular}

\section{Phylogenetic Analysis}

In this phylogeny nucleotide sequence data of 17 species together with 49 strains or taxa of $G$. lucidum species complex from Asia, America and Europe were obtained from GenBank. Molecular 
data comprised 5.8S-ITS rDNA, 20 EF-1 $\alpha, 20$ RPB1 sequence data from 49 strains (Table 3). The initial alignment was done in MEGA 5.05 (Tamura et al. 2011) and then manually using BioEdit v. 7.2 (Hall 1999) and ClustalX (Kohli and Bachhawat 2003). Trametes versicolor (L.) Lloyd. 1921 (EU273523) was selected as the out group taxon. Maximum Parsimony analysis was performed with PAUP version 4.0b10 (Swofford 2001) using a Heuristic search and TBR (tree bisectionreconnection) swapping for 1000 random replicates. Gaps were set as "missing" data and the characters were specified as unordered and equally weighted for bootstrap analysis (Hillis \& Bull 1993) performed with 1000 replications with simple addition sequences to obtain estimates of reliability for nodes. The concatenated dataset resulted in an alignment comprising 2477 characters, of which 1774 are constant, 352 parsimony-uninformative and 351 parsimony-informative. Topology, along with BS values by MP analyses above 50\% is shown above the branches.

Table 3 Sequences used in the phylogenetic analysis.

\begin{tabular}{|c|c|c|c|c|c|c|}
\hline Species & $\begin{array}{l}\text { Voucher / } \\
\text { strain }^{1,2}\end{array}$ & Origin & 5.8 ITS & RPB1 & $\mathbf{E F}-\mathbf{1 \alpha}$ & Reference \\
\hline Ganoderma ahmadii & FWP 14329 (type) & Pakistan & Z37047 & - & - & $\begin{array}{l}\text { Smith \& } \\
\text { Sivasithamparam } \\
(2000 a)\end{array}$ \\
\hline Ganoderma boninense & WD2085 (FFPRI) & Japan & KJ143906 & KJ143945 & KJ143925 & Zhou et al. 2014 \\
\hline Ganoderma boninense & WD2028 (FFPRI) & Japan & KJ143905 & KJ143944 & KJ143924 & Zhou et al. 2014 \\
\hline Ganoderma carnosum & $\mathrm{K}(\mathrm{M}) 109415$ & UK & AY884175 & - & - & $\begin{array}{l}\text { Genbank } \\
\text { unpublished }\end{array}$ \\
\hline Ganoderma carnosum & MQN001 (NARC) & $\begin{array}{l}\text { Phulchoki } \\
\text { Mountain, } \\
\text { Nepal }\end{array}$ & AB763348 & - & - & $\begin{array}{l}\text { Genbank } \\
\text { unpublished }\end{array}$ \\
\hline Ganoderma flexipes & Wei5200 (IFP) & & JN383978 & - & - & Cao \& Yuan 2013 \\
\hline Ganoderma flexipes & Wei5494 (IFP) & Hainan, China & JN383979 & - & - & Cao \& Yuan, 2013 \\
\hline Ganoderma lingzhi & $\begin{array}{l}\text { HKAS76642 (Iso } \\
\text { type) }\end{array}$ & Yunnan, China & $\mathrm{KC} 222318$ & - & - & Yang \& Feng 2013 \\
\hline Ganoderma lingzhi & Dai12574 (IFP) & $\begin{array}{l}\text { Liaoning, } \\
\text { China }\end{array}$ & KJ143908 & JX029985 & JX029977 & Cao et al 2012 \\
\hline Ganoderma lingzhi & Cui9166 (BJFC) & $\begin{array}{l}\text { Shandong, } \\
\text { China }\end{array}$ & KJ143907 & JX029982 & JX029974 & Cao et al 2012 \\
\hline Ganoderma lingzhi & HSD06B & $\begin{array}{l}\text { Taihang } \\
\text { mountains, } \\
\text { China }\end{array}$ & KC511557 & - & - & $\begin{array}{l}\text { Genbank } \\
\text { unpublished }\end{array}$ \\
\hline Ganoderma lucidum & $\begin{array}{l}\text { RYV } 33217 \\
\text { (Lectotype) }\end{array}$ & 7Norway & Z37096 & - & - & $\begin{array}{l}\text { Smith \& } \\
\text { Sivasithamparam } \\
\text { (2000a) }\end{array}$ \\
\hline Ganoderma lucidum & Dai11593 (IFP) & Finland & JQ781852 & - & - & Cao et al 2012 \\
\hline Ganoderma lucidum & K175217 & UK & KJ143911 & KJ143950 & KJ143929 & Zhou et al. 2014 \\
\hline Ganoderma lucidum & MT2610 (BRNM) & $\begin{array}{l}\text { Czech } \\
\text { Republic }\end{array}$ & KJ143912 & KJ143951 & KJ143930 & Zhou et al. 2014 \\
\hline Ganoderma lucidum & BR 4195 (Rivoire) & France & KJ143909 & KJ143948 & - & Zhou et al. 2014 \\
\hline Ganoderma lucidum & Cui 9207 (BJFC) & Yunnan, China & $\mathrm{KJ} 143910$ & KJ143949 & KJ143928 & Zhou et al. 2014 \\
\hline Ganoderma lucidum & Dai2272 (IFP) & Sweden & JQ781851 & - & - & Cao et al. 2012 \\
\hline Ganoderma lucidum & КCTC 6531 & Korea & AF248341 & - & - & Yang \& Feng 2013 \\
\hline Ganoderma lucidum & HKAS76455 & $\begin{array}{l}\text { Yunnan, } \\
\text { China(Cultivat } \\
\text { ed) }\end{array}$ & KC222320 & - & - & Yang \& Feng 2013 \\
\hline Ganoderma lucidum & HKAS48969 & Yunnan, China & $\mathrm{KC} 222323$ & - & - & Yang \& Feng 2013 \\
\hline Ganoderma lucidum & HKAS71088 & Yunnan, China & $\mathrm{KC} 222321$ & - & - & Yang \& Feng,2013 \\
\hline Ganoderma lucidum & OE-234 & India & AY636059 & - & - & $\begin{array}{l}\text { Genbank } \\
\text { unpublished }\end{array}$ \\
\hline Ganoderma lucidum & GlCN04 & Italy & AM906058 & - & - & Cao \& Yuan, 2012 \\
\hline
\end{tabular}




\begin{tabular}{|c|c|c|c|c|c|c|}
\hline Species & $\begin{array}{l}\text { Voucher / } \\
\text { strain }\end{array}$ & Origin & 5.8 ITS & RPB1 & $\mathbf{E F}-1 \alpha$ & Reference \\
\hline Ganoderma lucidum & G1T099 & Italy & AM269773 & - & - & Cao \& Yuan 2012 \\
\hline Ganoderma multipileum & $\begin{array}{l}{ }_{2 W N} \\
04670(\mathrm{TNM})\end{array}$ & Taiwan, China & KJ143913 & KJ143952 & KJ143931 & Zhou et al. 2014 \\
\hline Ganoderma multipileum & $\imath$ HMAS242384 & $\begin{array}{l}\text { Sichuan } \\
\text { Province, } \\
\text { China }\end{array}$ & JF915409 & - & - & Wang et al. 2012 \\
\hline Ganoderma multipileum & $\imath$ Dai 9447(IFP) & Hainan, China & KJ143914 & KJ143953 & KJ143932 & Zhou et al. 2014 \\
\hline Ganoderma multipileum & $\imath \mathrm{DYU}$ & Taiwan, China & KJ868083 & - & - & $\begin{array}{l}\text { Genbank, } \\
\text { unpublished }\end{array}$ \\
\hline Ganoderma oerstidii & GO138 & Argentina & DQ425011 & - & - & $\begin{array}{l}\text { Genbank } \\
\text { Unpublished }\end{array}$ \\
\hline Ganoderma oregonense & ATCC 46750 & Canada & Z37061 & - & - & $\begin{array}{l}\text { Genbank } \\
\text { Unpublished }\end{array}$ \\
\hline Ganoderma pfeifferi & CBS 747.84 & Netherlands & JQ520198 & - & - & Park et al. 2012 \\
\hline Ganoderma pfeifferi & $\mathrm{K}(\mathrm{M}) 120818$ & UK & AY884185 & - & - & Park et al. 2012 \\
\hline Ganoderma pfeifferi & 874 (CAS-IM) & $\begin{array}{l}\text { Czech } \\
\text { Republic }\end{array}$ & AM906059 & - & - & Guglielmo 2008 \\
\hline Ganoderma resinaceum & BR 4150(Rivoire) & France & KJ143915 & KJ143957 & - & Zhou et al. 2014 \\
\hline Ganoderma resinaceum & Gre4 & Italy( Modena) & KJ509598 & - & - & $\begin{array}{l}\text { Genbank } \\
\text { Unpublished }\end{array}$ \\
\hline Ganoderma sessile & NY 00985711 & $\mathrm{USA}(\mathrm{NJ})$ & KJ143918 & - & - & Zhou et al. 2014 \\
\hline Ganoderma sessile & $\begin{array}{l}\text { LDW } \\
\text { (IFP) }\end{array}$ & 7USA(CT) & KJ143917 & - & KJ143935 & Zhou et al. 2014 \\
\hline $\begin{array}{l}\text { Ganoderma } \\
\text { sichuanense }\end{array}$ & $\begin{array}{l}\text { CGMCC5.2175 } \\
\text { (epitype) }\end{array}$ & $\begin{array}{l}\text { Sichuan, } \\
\text { China }\end{array}$ & КС662402 & - & - & Yao et al. 2013 \\
\hline $\begin{array}{l}\text { Ganoderma } \\
\text { sichuanense }\end{array}$ & $\begin{array}{l}\text { HMAS } \\
\text { (Holotype) }\end{array}$ & 8Sichuan China & JQ781877 & - & - & Zhou et al. 2014 \\
\hline Ganoderma tropicum & $\begin{array}{l}\text { BCRC } 37122 \\
\text { (TNM) }\end{array}$ & Taiwan, China & EU021457 & - & - & Wang \&Wu 2007 \\
\hline Ganoderma tropicum & Yuan 3490 (IFP) & Yunnan, China & JQ781880 & - & KJ143938 & $\begin{array}{l}\text { Cao et al } 2012 \text { and } \\
\text { Zhou et al. } 2014\end{array}$ \\
\hline Ganoderma tsugae & Dai3937 (IFP) & China & JQ781853 & - & - & Cao et al. 2012 \\
\hline Ganoderma tsugae & Dai 12760 (IFP) & $\mathrm{USA}(\mathrm{CT})$ & KJ143920 & KJ143961 & KJ143940 & Zhou et al. 2014 \\
\hline Ganoderma valesiacum & CBS 428.84 & USA & JQ520218 & - & - & Park et al. 2012 \\
\hline Ganoderma valesiacum & CBS 282.33 & UK & Z37056 & - & - & $\begin{array}{l}\text { Moncalvo et al } \\
1994\end{array}$ \\
\hline Ganoderma zonatum & FL02 (TNM) & USA(FL) & KJ143921 & KJ143962 & KJ143941 & Zhou et al. 2014 \\
\hline Ganoderma zonatum & FL03 (TNM) & USA(FL) & KJ143922 & - & KJ143942 & Zhou et al. 2014 \\
\hline Trametes versicolor & XSD-4 & EU273523 & & & & $\begin{array}{l}\text { Genbank } \\
\text { unpublished }\end{array}$ \\
\hline
\end{tabular}

* ATCC, American Type Culture Collection, Maryland, USA, BJFC, Beijing Forestry University, BRNM, Moravian Museum in Brno, CAS-IM, Academy of Sciences of Czech Republic Institute of Microbiology Department of Experimental Mycology, Videnska, Czech Republic, CBS, Centraalbureau voor Schimmelcultures, Utrecht, the Netherlands, CGMC China General Microbiological Culture Collection Center, Chinese Academy of Sciences, Di. Va.P.R.A, Department of Exploitation and Protection of the Agricultural and Forestry resources, University of Torino, Grugliasco (Italy),FFPRI ,the Forest Products Research Institute, FWP, Fungi of West Pakistan, Jardin Botanique de Belgique, Belgium, HMAS, Mycological Herbarium of the Institute of Microbiology, Chinese Academy of Sciences, HKAS, Kunming Institute of Botany, Chinese Academy of hidden flowers herbarium, IFP, Institute of Applied Ecology, Chinese Academy of Sciences, JV, The private herbarium of Josef Vlasak, KEW, the Royal Botanical Garden, Kew, Surrey, UK,KTCC, Korean Type Culture Collection, NARC, Nepal Agricultural Research Center, NY, the New York Botanical Garden, Rivoire, the private collection of Bernard Rivoire, RYV, Herbarium of Leif Ryvarden, Oslo, Norway, TNM, the Herbarium of the National Museum of Natural Science.

* Type specimens are in bold. 


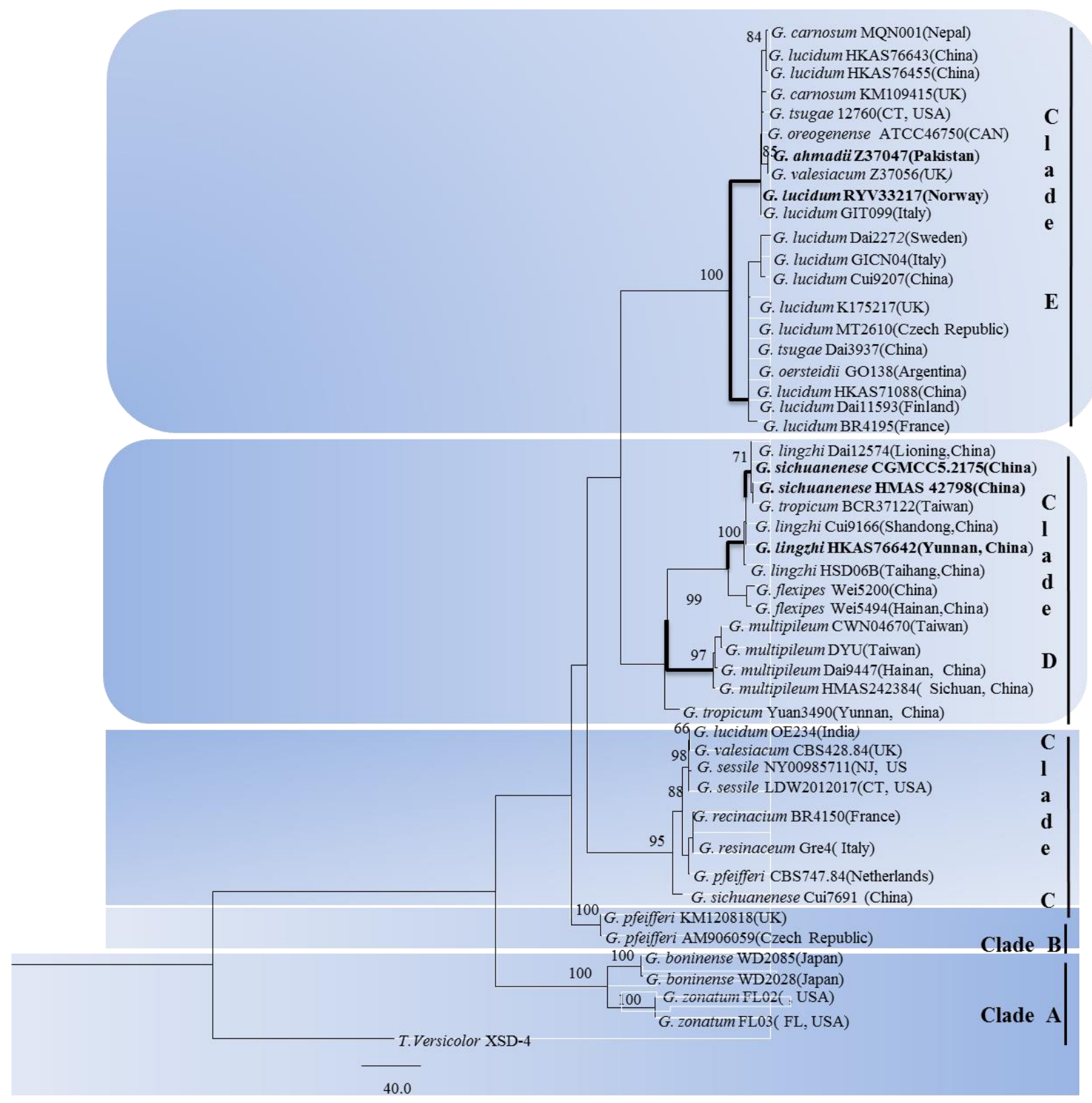

Fig. 2 - Phylogeny of the Ganoderma lucidum species complex based on the data from a combination 5.8S-ITS rDNA, EF-1 $\alpha$ and RPB1 genes. Topology and bootstrap values were obtained from maximum parsimony above $50 \%$. The tree is rooted to Trametes versicolor (XSD4). All ex-type strains are in bold.

\section{Results and Discussion}

In the current phylogeny, the 49 specimens and strains from the G. lucidum species complex representing 17 species with high support values. These 17 species are G. ahmadii (85), G. boninense (100), G. carnosum (84), G. flexipes, G. lingzhi (100), G. lucidum (100), G. multipileum (97), G. oerstidii, G. oregonense, G.pfeifferi (100), G. resinaceum, G. sessile (98) G. sichuanense (71), G. tropicum, G. tsugae, G. valesiacum and G. zonatum (100). In the presented phylogeny 17 species from the Ganoderma lucidum species complex clustered into five clades (Clade A, B, C, D and $\mathrm{E}$ in Figure 2) even though some of them are from similar environments. Hence, the evolutionary histories for these species are unclear and the morphology data and the geographical distributions themselves are not sufficient to place them in a correct order. More data is needed from other laccate species as well non laccate species to clarify the taxonomic position of species in the Ganoderma lucidum complex. 
Table 4 Recommended taxa for Ganoderma lucidum species complex.

\begin{tabular}{ll}
\hline Taxa & References \\
\hline Ganoderma ahmadii Stey. & Steyaert 1972 \\
${ }^{*}$ Ganoderma lingzhi Wu et al. & Cao et al. 2012 \\
${ }^{*}$ Ganoderma lucidum (Curtis) P. Karst & Karsten 1881 \\
${ }^{*}$ Ganoderma multipileum D. Hou. & Hou 1950 \\
Ganoderma oerstedii (Fr.) Torr. & Adaskaveg \& Gilbertson 1986 \\
Ganoderma oregonense Murr. & Murril 1908 \\
Ganoderma pfeifferi Bres. & Bazzalo \& Wright. 1982 \\
Ganoderma resinaceum Boud. & Patouillard 1889 \\
Ganoderma sessile Murrill. & Murril 1902 \\
${ }^{*}$ Ganoderma sichuanense J.D. Zhao \&X.Q. Zhang. & Zhao et al. 1983 \\
Ganoderma tsugae Murr. & Murril 1902 \\
Ganoderma valesiacum Boud. & Murril 1908 \\
Ganoderma zonatum Murrill. & Murril 1902 \\
\hline
\end{tabular}

*Suggested species that need further work on taxonomy.

\section{Species in clade $\mathbf{A}$}

Two species from Japan and USA, Ganoderma zonatum and G. boninense clustered in clade A (Figure 2). They are subtropical species and thus G. boninense is the correct name for G. lucidum species in America. Gottlieb et al. (2000) found, G. sessile and G. zonatum are conspecific based on ITS phylogeny, whereas Zhou et al. (2014) showed that they are two independent species with the help of molecular and morphological data by observing specimens from the type localities. Zhou et al. (2014) clearly distinguished G. boninense, from G. sessile and G. tsugae.

\section{Species in clade $B$}

Two strains of G. pfeifferi, a wood rooting taxon from the UK and Czech Republic, clustered in clade B (Figure 2). Another strain of G. pfeifferi clustered in clade C. Ganoderma pfeifferi seems restricted to Eurasia with a few records in Eastern regions (Corner et al. 1983). Ganoderma pfeifferi species fit in the G. lucidum complex (Hseu et al.1996, Wang et al. 1996), but Cao \& Yuan (2012) stated in their phylogenetic study, that G. pfeifferi does not cluster with G. lucidum, but mostly resembles $G$. resinaceum, a species, that has mistakenly been placed in the G. lucidum group. In our study, G. pfeifferi does not belong to the G. lucidum species complex since G. pfeifferi specimens had clustered separately, as clade B (Figure 2). However G. pfeifferi specimen from Netherland clustered with $G$. resinaceum in clade B. This led us to believe that there are differences even within the European specimens based on type locality and questioning the reliability of the nucleotide sequences used.

\section{Species in clade $\mathbf{C}$}

Five species clustered in clade C: Ganoderma sichuanense from China, a collection of $G$. pfeifferi (described in clade B) from Netherlands, G. resinaceum from France and Italy, G. sessile from USA, G. valesiacum from UK and G. lucidum from India. The G. lucidum strain from India is distinct from all other G. lucidum species from Europe and China (Figure 2).

This indicates that the South Indian $G$. lucidum species mostly resembles the European $G$. resinaceum and American G. sessile. Wang et al. (2009) showed the Indian strain of G. lucidum to be consistent with $G$. multipileum. The nucleotide sequences and the nomenclature of the Indian specimen are doubtful since it forms a distinct lineage in the phylogenic tree. This specimen is phylogenetically more close to G. lingzhi and G. multipileum from China (Figure 2).

One G. valesiacum strain clustered in Clade C (Figure 2). Hseu et al. (1996) stated that this species belongs to the G. lucidum species complex, however one of the strains had clustered with G. lucidum (Clade E) and one strain has delineated and clustered with G. sessile group in clade C (Figure 2). Both taxa were from the UK. Ganoderma lucidum and G. valesiacum are synonyms 
according to morphological observations of Steyaert (1972). Moncalvo (1996) reported that $G$. valesiacum and $G$. lucidum were different species, even $G$. valesiacum clustered with G. lucidum based on his molecular data. Ganoderma sessile was described from New York, USA by Murrill 1902 (Zhou et al. 2014) and was treated as a synonym of G. resinaceum by Haddow (1931), while Overholts (1953) considered that G. lucidum should be the correct name for specimens classified as G. sessile. Nobles (1965) pointed out that the specimens classified as G. lucidum in the USA actually represented $G$. sessile. She therefore changed the names of her species previously listed as G. lucidum to G. sessile. Furthermore, Steyaert (1972) considered G. sessile a synonym of $G$. resianceum (Adaskaveg \& Gilbertson 1986). Gottlieb et al. (2000) provided evidence that $G$. sessile is conspecific with G. zonatum based on ITS phylogeny and considered their differences in morphology to be a result of divergent evolution. Zhou et al. (2014) clearly showed that G. sessile is a distinct species from $G$. zonatum based on his phylogenetic analysis.

Staplers (1978) believed that Ganoderma resinaceum is the correct name for the fungus described as G. lucidum. Steyaert (1980) and Ryvarden (1985) considered numerous names as synonyms of Ganoderma resianceum. Monocalvo et al. (1995) strongly suggested that $G$. resinaceum was different from $G$. lucidum and probably belongs to G. pfeifferi. Cultural characteristics and morphological observations of the basidiocarp and basidospores supported this observation (Wang \& Hua 1991, Ryvarden \& Gilbertson 1993). Moncalvo et al. (1995) strongly believed that, based on molecular data, that G. resinaceum is a species complex. Hong \& Jung (2004) found that G. resinaceum could not be distinguished phylogenetically from G. lucidum (Mohanty et al. 2011). Ganoderma resinaceum was shown to be distinct from G. lucidum by Mohanty et al. (2011). Furthermore it was suggested that European species of G. resinaceum differed from G. lucidum species from Europe and China (Cao et al. 2012, Zhou et al. 2014). In our phylogeny the European species of G. resinacium clustered with G. pfeifferi (Figure. 2).

\section{Species in clade $\mathbf{D}$}

Ganoderma flexipes. G. lingzhi, G. multipileum, G. sichuanense and G. tropicum clustered in clade D (Figure 2). The validity of G. lingzhi and G. sichuanense has been recently debated. Wang \& Yao (2009) proposed that $G$. sichuanense can represent ' $G$. lucidum' in China. With the aid of molecular phylogeny, Wang et al. (2009) divided Asian specimens classified as G. lucidum into two clades; both clades were separated from the European G. lucidum. One clade, composed of tropical collections, represented $G$. multipileum, while the other clade is unnamed. As $G$. sichuanense had previously been described, Wang et al. (2009) proposed this name for G. lucidum in China. In parallel, Cao et al. (2012) found that the holotype of G. sichuanense was not conspecific with the unnamed clade, and proposed it as a new species called Ganoderma lingzhi, which was considered to be the most widely cultivated species in China. Yao et al. (2013) proposed $G$. sichuanense and $G$. lingzhi as synonymous based on morphological data from an epitype of $G$. sichuanense. However Zhou et al. (2014) again challenged this opinion, with G. lingzhi and G. sichuanense being an independent and taxonomically valid species by stressing that species types depends on geographical distributions. In our phylogeny some strains (G. sichuanense Cui 7691) clustered with G. resinaceum, G. pfeifferi and G. sessile, while others were clustered with $G$. lingzhi (Figure 2).

Ganoderma sichuanense is distantly related to $G$. lingzhi, but it is phylogenically close to $G$. resinaceum, although they are morphologically distinct (Cao et al. 2012). Our studies phylogenically verified the idea that $G$. sichuanense was closely related to $G$. resinaceum; hence the Chinese strain from Guangdong Province, clustered with G. resinaceum in clade C (Figure.2). In addition, we suggest that G. sichuanense is phylogenetically closely related to G. lingzhi, since the strain from Sichuan, China, had clustered with G. lingzhi in clade D. According to previous studies, we suppose that G. lucidum, G. sichuanense and G. lingzhi are three independent species in China, however further critical clarification is needed using morphological data with type species supported by molecular data. 
Phylogenetic evidence indicates that G. tropicum is a distinct species (Cao et al. 2012, Wang et al. 2012, Yang \& Feng 2013, Li et al. 2013, Zhou et al. 2014) and this species can be widely found across subtropical and tropical Asia (Moncalvo \& Ryvarden 1997). Some researchers have shown in their phylogenies that G. tropicum is phylogenically more similar to G. multipileum (Wang et al. 2012, Cao et al. 2012). Ganoderma tropicum resembles G. multipileum in morphology and habitat even though they are distinct species (Wang et al. 2009). In the present phylogeny one of the strains of G. tropicum from Taiwan clustered with G. sichuanense, while the other from Yunnan Province, China, clustered with G. multipileum (Figure 2). Hence, the G. tropicum strain from Taiwan is phylogenically more similar to G. sichuanense, whereas the other strains from Yunnan Province are phylogenically more similar to G. multipileum.

Ganoderma atrum J.D. Zhao et al. G. calidophilum J.D. Zhao et al. G. hainanense J.D. Zhao et al. and G. parviungulatum J.D. Zhao \& X.Q. Zhang, are described from Hainan Province, China by J.D. Zhao and his colleagues, but they are synonyms of G. flexipes (Cao et al. 2012). Cao \& Yuan (2012) showed that G. flexipes from China nested with G. philippii from Malaysia and G. fornicatum. Li et al. (2013) found G. flexipes from China nested with Chinese G. lingzhi, G. multipileum, G. tropicum and G. curtsii. With the aid of molecular evidence many researchers reported G. flexipes species in China are more similar to G. lingzhi, G. multipileum and G. tropicum species found in China. (Cao et al. 2012, Yang \& Feng 2013, Zhou et al. 2014). Our studies confirmed the same opinion. G. multipileum can be found in tropical China and other tropical Asian countries, such as India and Philippines (Cao et al. 2012). Ganoderma multipileum species had previously been misidentified as G.lucidum (Zhou et al. 2014). As stated above, Wang (2009a) found that the Chinese G. lucidum species is actually G. multipileum.

\section{Species in clade $\mathbf{E}$}

Ganoderma lucidum, the generic type, G. tsugae, G. oerstidii, G. carnosum, G. oregonense, G. ahmadii and G. valesiacum cluster in clade E (Figure 2). Moncalvo et al. (1995) used molecular data to conclude that $G$. oregonense belongs to the $G$. valesiacum species complex and clearly identified the American specimen labeled as G. lucidum as G. oregonense. This was subsequently followed by various researchers (Cao et al. 2012, Zhou et al. 2014), who considered G. lucidum and $G$. oreogenense as to be distinct species. In our phylogeny, (Figure 2), G. oregonense clustered with G. lucidum and hence it is more close to Chinese G. lucidum sensu lato phylogenically, than the European G. lucidum. Moncalvo et al. (1995) found $G$. carnosum was a species in the $G$. valesiacum species complex since it was phylogenically similar to $G$. valesiacum based on molecular data; however these two species were morphologically very different from each other.

Ganoderma ahmadii was reported only from Pakistan, India and South China (Steyaert 1972, Zhao 1989). Moncalvo et al. (1995) found G. ahmadii was a morphologically and phylogenetically distinct species. After that many of the researches followed Moncalvo's data (Hseu et al.1996, Smith \& Sivasithamparam 2000, Li et al. 2013) for their studies, but this species has not been discussed broadly. Our phylogenetic tree showed G. ahmadii clustered with European $G$. valesiacum; hence this species is phylogenically more close to European G. valesiacum (Figure 2). Ganoderma tsugae might be conspecific with $G$. valesiacum as these taxa have morphological, ecological and cultural similarities (Stalpers 1978). This was followed by Adaskaveg \& Gilbertson (1986), Gilbertson \& Ryvarden (1986); however, Moncalvo (1995) found G. tsugae was a distinct species in the G.valesiacum group, based on morphological and molecular observations. Many researchers have confirmed with molecular data that G. tsugae is a distinct species from G. lucidum (Wang \& Yao 2005, Smith \& Sivasithamparam 2000, Li et al 2013, Yang \& Feng 2013, Zhou et al. 2014). In our phylogeny (Figure 2), the G. tsugae specimen from the USA is phylogenetically closely related to the Asian G. lucidum, but less close to the European G. lucidum. The Chinese strain of G. tsugae is very close to the European G. lucidum phylogenically.

Ganoderma oerstidii was described from Argentina and it is a distinct species which differs from G. lucidum both morphologically and phylogenically (Moncalvo et al.1995, Figure 1). Earlier this species has been misidentified as G. lucidum. 


\section{Drawbacks}

Lack of multigene nucleotide sequence data and lack of careful morphological study of species of Ganoderma lucidum are the main challenges. Hence classification of the species is a difficult task.

\section{Future studies}

To resolve the relationships and taxonomic issues among $G$. lingzhi, G. sichuanense, $G$. lucidum and other species in the complex, an epitype for G. sichuanense and for G. lingzhi should be selected from their type locality, and nucleotide sequences of more informative DNA markers should be used to delimit the species in the complex.

\section{Acknowledgements}

This work was financed by the Science and Technology Foundation of Guizhou Province (No. [2012]3173), the Science Research Foundation of Guizhou University (No. 201309), the Modernization of Traditional Chinese Medicine Program of Guizhou Province (No. [2012]5008), Natural Science Foundation of Hainan Province of China (31409) and Thailand Research Fund grant - Taxonomy, Phylogeny and biochemistry of Thai Basidiomycetes (BRG 5580009).

\section{References}

Adaskaveg JE, Gilbertson RL. 1988 - Basidiospores, pilocystidia, and other basidiocarp characters in several species of the Ganoderma lucidum complex. Mycologia 80, 493-507.

Adaskaveg JE, Gilbertson RL. 1986 - Culture studies and genetics of sexuality of Ganoderma lucidum and G. tsugae in relation to the taxonomy of the G. lucidum complex. Mycologia 78, 694-705.

Adaskaveg JE, Blanchette RA, Gilbertson RL. 1991 - Decay of date palm wood by white-rot and brown- rot fungi. Canadian Journal of Botany 69, 615-629.

Anon. 1955 -.Shen Nong materia medica, 102-200 A.D (E. Han). Reprinted. People Hygiene Press, Beijing.

Bazzalo ME, Wright JE. 1982 - Survey of the Argentine species of the Ganoderma lucidum complex. Mycotaxon 16, 295-325.

Blackford FW. 1944 - A Ganoderma root rots of citrus. Queensland Journal of Agricultural Science 1,77-81.

Bhosle S, Ranadive K, Bapat G, Garad S, Deshpande G, Vaidya J. 2010 - Taxonomy and Diversity of Ganoderma from the Western parts of Maharashtra (India). Mycosphere 1(3), 249-262.

Boudier E. 1895 - Description de quelquesnouvelles espèces de Champignons recoltées dans les regions elevées des Alpes du Valais, en aout 1894. Bulletin de la Société Mycologique de France 11, 27-30.

Boh B, Berovic M, Zhang J, Zhi-Bin L. 2007 - Ganoderma lucidum and its pharmaceutically active compounds. Biotechnol. Annu. Rev. 13, 265-301.

Cao Y, Wu SH, Dai YC. 2012 - Species clarification of the prize medicinal Ganoderma mushroom “'Lingzhi'”. Fungal Divers. 56, 49-62.

Cao Y, Yuan. HS. 2013 - Ganoderma mutabile sp. nov. from southwestern China based on morphological and molecular data Mycol Progress 12, 121-126.

Chang ST, Buswell JA. 1999 - Ganoderma lucidum (Curt. Fr.) P. Karst. (Aphyllophoromycetideae) - A mushrooming medicinal mushroom. Int J Med Mush 1, 139146.

Chen CS. 1993 - Methods for inducing various morphological fruiting body of Ganoderma tsugae Murr. Trans Mycol Soc Republ China 8, 9-16.

Cooke MC. 1883 - Fungi Australiani. Melbourne, Australia.

Cooke MC. 1885 - Prñcursores admonographiapolypororum. Grevillia 14:17-21.

Cooke MC. 1892 - Handbook of Australian Fungi. Williams and Norgate, London, UK.

Corner EJH. 1983 - Ad Ployporaceas I. Amauroderma and Ganoderma. Nova Hedwigia, 75. 1182. 
Curtis W. 1781 - Flora Londinensis: or plates and descriptions of such plants as grow wild in the environs of London. London: printed by the author. $530 \mathrm{p}$.

Donk MA. 1948 - Notes on Malaysian fungi. I Bull du Jard Bot Buitenzorg 17:473-482.

Dai YC, Cui BK, Yuan HS, Li BD. 2007a - Pathogenic wood-decaying fungi in China. Forest Pathol 37, 105-120.

Dai YC, Vainio EJ, Hantula J, Niemelä T, Korhonen K. 2003 - Investigation on Heterobasidion annosum s.lat. in central and eastern Asia with the aid of mating tests and DNA fingerprinting. For Path 33, 269-28.

Dai YC, Yang ZL. Cui BK, Yu CJ, Zhou LW. 2009 - Species diversity and utilization of medicinal mushrooms and fungi in China. Int J Med Mushr 11, 287-302.

De Silva DD, Rapior S, Fons F, Bahkali AH, Hyde KD. 2012 - Medicinal mushrooms in supportive cancer therapies: an approach to anti-cancer effects and putative mechanisms of action. Fungal Divers 55, 1-35.

De Silva DD, Rapior S, Sudarman E, Stadler M, Xu J, Alias SA, Hyde KD. 2013 - Bioactive metabolites from macrofungi: ethnopharmacology, biological activities and chemistry, Fungal Diversity, vol. 62, pp. 1-40.

De Silva DD, Rapior S, Hyde KD, Bahkali AH. 2012 - Medicinal mushrooms in prevention and control of diabetes mellitus. Fungal Diversity, vol. 56, pp. 1-29.

Ekandjo LK, Chimwamurombe PM. 2012 - Traditional Medicinal Uses and Natural Hosts of the Genus Ganoderma in North-Eastern Parts of Namibia. J. Pure Appl. Microbiol. 6(3), 1139-1146.

Fries EM. 1821 - Systema Mycologicum, sistens fungorum ordines, genera etspecies. Vol. 1. Gryphiswaldiae: Sumtibus Ernesti Mauritti. 353 p.

Gao Y, Zhou S, Huang M, Xu A. - 2003. Antibacterial and antiviral value of the Genus Ganoderma P. Karst. Species (Aphyllophoromycetideae): A review. int j med mush 5, 235246.

Gilbertson RL, Ryvarden L. 1986 - North American Polypores 1. Fungi flora, Oslo.

Glen M, Bougher NL, Francis AA, Nigg SQ, Lee SS, Irianto R, Barry KM, Beadle CL, Mohammed CL. 2009 - Ganoderma and Amauroderma species associated with root-rot disease of Acacia mangium plantation trees in Indonesia and Malaysia. Australasian Plant Pathology, 38, 345-356.

Gottlieb AM, Ferrer E, Wright JE. 2000 - rDNA analyses as an aid to the taxonomy of species of Ganoderma. Mycol. Res. 104, 1033-1045.

Haddow WR. 1931 - Studies in Ganoderma. J. Arnold Arbor. 12, 25-46.

Hall TA. 1999 - BioEdit: a user-friendly biological sequence alignment editor and analysis program for Windows 95/98/NT. In: Nucleic Acids Symposium Series 41, 95-98

Hawksworth DL. 2005 - Reflections on changing names and related nomenclatural issues in edible and medicinal mushrooms. Int J Med Mushrooms 7, 29-38.

Hepting GH. 1971 - Diseases of forest and shade trees of the United States. US Department of Agriculture, Agricultural Handbook 386, 1-658.

Hillis DM, Bull JJ. 1993 - An empirical test of bootstrapping as a method for assessing confidence in phylogenetic analysis. Syst. Biol. 42, 182-192.

Hou D. 1950 - A new species of Ganoderma from Taiwan.Quat. J. Taiwan Mus. 3,101-105.

Hong SG, Jeong W, Jung HS, 2002 - Amplification of mitochondrial small subunit ribosomal DNA of polypores and its potential for phylogenetic analysis. Mycologia 94, 823-833.

Hong SG, Jung HS, 2004 - Phylogenetic analysis of Ganoderma based on nearly complete mitochondrial small-subunit ribosomal DNA sequences. Mycologia 96, 742-755.

Hong KK, Geon SS, Hong GK. 2001 - Comparison of characteristics of Ganoderma lucidum according to geographical origins: Consideration of morphological characteristics. Micobiology, 29, 80-84.

Hseu RS, Wang HH, Wang HF, Moncalvo JM. 1996 - Differentiation and grouping of isolates of the Ganoderma lucidum complex by random amplified polymorphic DNA-PCR compared 
with grouping on the basis of internal transcribed spacer sequences. Appl Environ Microbiol 62, 1354-1363.

Idris AS, Mazliham MS, Loonis P, Wahid MB. 2010 - GanoSken for Early Detection of Ganoderma Infection in Oil Palm. POB Information Series TT No. 442, p. 4.

Imazeki R. 1952 - A contribution to the fungus flora of Dutch New Guinea. Bull Govt for Exp St Tokyo 57:87-128.

Index Fungorum: http://www.indexfungorum.org (accessed 11 September 2015)

Jong SC, Birmingham JM. 1992 - Medicinal benefits of the mushroom Ganoderma.Adv Appl Microbiol 37, 101-134.

Karsten PA. 1881- Enumeralio boletinearum et polypore arum fennicarum, systemate novo dispositarum. Rev. Mycol. 3, 16-19.

Kinge TR, Mih AM. 2011 - Ganoderma ryvardense sp. nov. associated with basal stem rot (BSR) disease of oil palm in Cameroon. Mycosphere 2(2), 179-188.

Kirk PM, Cannon PF, Minter DW, Stalpers JA. 2008 - Dictionary of the fungi. 10th ed., p. 272.

Kohli DK, Bachhawat AK. 2003 - Cloure: Clustal Output Reformatter, a program for reformatting ClustalX/ClustalW outputs for SNP analysis and molecular systematics. Nucleic Acids Research 31, 3501-3502.

Lai T, Gao Y, Zhou SF. 2004 - Global marketing of medicinal Ling Zhi mushroom Ganoderma lucidum (W.Curt:Fr.) Lloyd (Aphyllophoromycetideae) products and safety concerns. Int J Med Mushr 6:189-194.

Lan J, Xujt, Wang QY. 1998 - Electrophoretic studies on esterase and peroxidase isozyme in Ganoderma sp. Chin Pharm J 33, 12-4.

Li J, Zhang J, Chen H, Chen X, Lan J. 2013 - Complete Mitochondrial Genome of the Medicinal Mushroom Ganoderma lucidum. PLoS ONE 8(8), 72038.

Li TH, Hu HP, Deng WQ, Wu SH,Wang DM. Tsering T. 2014 - Ganoderma leucocontextum, a new member of the G. lucidum complex from southwestern China. Mycoscience 56, 8185.

Lin SB, Li CH, Lee SS, Kan LS. 2003 - Triterpene-enriched extracts from Ganoderma lucidum inhibit growth of hepatoma cells via suppressing protein Kinase C, activating mitogenactivated protein kinases and G2-phase cell cycle arrest. Life Sci 72, 2381-2390.

Lin ZB 2009 - Lingzhi: from mystery to science. Peking University Medical Press, Beijing, pp 1162.

Liu B. 1974 - The Chinese medical fungi. Shanxi People's Press, Taiyuan, pp 1-196, in Chinese.

Liu X, Yuan, Chung CK, Chen XJ. 2002- Anti-tumor activity of the sporoderm broken germinating spores of Ganoderma lucidum. Cancer Lett, 182:155-61.

Martinez AT, Barrasa JM, Martinez MJ, Almendros G, Blancom, Gonzalez AE. 1994 Ganoderma australe: A fungus responsible for extensive delignification of some Austral hardwoods. In: Buchanan PK, Hseu RS, Moncalvo M. 1994 - eds Ganoderma: systematics, phytopathology and pharmacology. Proceedings of contributed symposium 59A, B, $5^{\text {th }}$ International Mycological Congress. Vancouver, August 14-21, p 67-77.

Mao XL. 1998 - Economic fungi of China. Science Press, Beijing, pp 1-762, in Chinese.

Mattock G., 2001 - Notes on British Ganoderma species: Emphasizing the annual species and $G$. carnosum, Field Mycology Volume 2(2), April.

Mcalpine D. 1895 - Systematic Arrangement of Australian Fungi. Government Printer, Melbourne, Australia.

Miller RNG, Holderness M, Bridge PD, Chung GF, Zakaria MH. 1999 - Genetic diversity of Ganoderma in oil palm plantings. Plant Pathology 48,595-603.

Mizuno T. 1995 - Bioactive biomolecules of mushrooms: food function and medicinal effect of mushroom fungi. Food Rev Int 11, 7-21.

Mohanty PS, Harsh NSK, Pandey A. 2011 - First report of Ganoderma resinaceum and G. weberianum from north India based on ITS sequence analysis and micromorphology. Mycosphere 2(4), 469-474. 
Moncalvo JM, Ryvarden L. 1997 - A nomenclatural study of the Ganodermataceae Donk. Fungi flora $10,1-114$.

Moncalvo JM. 2000 - Systematics Ganoderma. In Ganoderma Diseases of Perennial Crops (ed. J. Flood, P. D. Bridge and M. Holderness), pp. 23-45. CABI Bioscience, Egham, UK.

Moncalvo JM, Wang HF, Hseu, RS. 1995a - Gene phylogeny of the Ganoderma lucidum complex based on ribosomal DNA sequences. Comparison with traditional taxonomic characters. Mycological Res 99, 1489-1499.

Moncalvo JM, Wang HF, Wang HH, Hseu RS. 1995b - The use of ribosomal DNA sequence data for species identification and phylogeny in the Ganodermataceae. In Ganoderma: Systematics, Phytopathology and Pharmacology. Proceedings of Contributed Symposium 59AB. 5th International Mycological Conference (ed. PK Buchanan, RS Hseu and JM. Moncalvo), pp. 31-44. National Taiwan University, Taipei, Vancouver.

Monkai JM, Hyde K.D, Xu, Mortimer PE. 2014 - Diversity and Ecology of soil fungal communities in rubber plantation. Fungal Ecology (accepted)

Mueller GM, Shcmit JP, Leacock PR, Buyck B., Cifuentes J. 2007 - Global diversity and distribution of macro fungi. Biodiversity and Conservation, 16, 37-48.

Muller CI, Kumagai T, Okelly J, Seeram NP, Heber D, Koeffler HP. 2006. - Ganoderma lucidum causes apoptosis in leukemia, lymphoma and multiple myeloma cells. Leuk. Res. 30, 841848.

Murrill WA. 1908 - Polyporaceae (pars). N. Am. Flora 9, 73-131.Murrill, W.A., 1902. The Polyporaceae of North America. I. The genus Ganoderma. Bull. Torrey Bot. Club 29, 599608

Murrill WA. 1905 - Tomophagus for Dendrophagus. Torreya 5:197.

Mycobank: http:/ www.mycobank.org (accessed 23 December 2014).

Naher L, Yusuf UK, Ismail A, Tan SG, Mondal MMA. 2013 - Ecological status of Ganoderma and basal stem rot disease of oil palms (Elaeis guineensisJacq.) Australian Journal of crop sciences, AJCS 7(11):1723-1727.

Noble S MK. 1965 - Identification of cultures of wood-inhabiting Hymenomycetes. Can. J. Bot. 43, 1097-1139.

Nobles MK. 1948 -Studies in Forest Pathology, VI. Identification of cultures of wood-rotting fungi. Can. J. Res. 26: 281-431.

National Center for Biotechnology Information: http:/www.ncbi.nlm.nih.gov/ (accessed December 23 2014).

Nunez M, Ryvarden L. 2000-East Asian polypores 1.Ganodermataceae and Hymenochaetaceae. Synop.Fung. 13, 1-168.

Overholts LO. 1953 - The Polyporaceae of the United States, Alaska and Canada. University of Michigan Press, Ann Arbor.

Page RDM. 1996 - Treeview: an application to display phylogenetic trees on personal computers. Comput Appl Biosci, 12, 357-8.

Paterson RRM, 2006 - Ganoderma - a therapeutic fungal bio factory. Photochemistry 67, 19852001

Patouillard NT. 1889 - Le genre Ganoderma. Bull. Soc. Mycol. France 5, 64-80.

Pegler DN, Yao YJ. 1996 - Oriental species of Ganoderma section Ganoderma. In Wasser SP (ed). Botany and mycology for the next millennium: collection of scientific articles devoted to the $70^{\text {th }}$ Anniversary of Academician Sytnik KM. Kyiv: Kholodny NG Institute of Botany, National Academy of Sciences of Ukraine. Pp 336-347.

Pegler DN, Young TWK. 1973 - Basidiospores form in the British species of Ganoderma Karst. Kew Bull. 28:351-369.

Peng JT. 1990 - Identification and culture conservation of the wild Ganoderma species in Taiwan' Publication of the Taiwan Agricultural Research Institute, Wufeng Taichung, Taiwan.

Pilotti CA, Sanderson FR, Aitken AB, Armstrong W. 2004 -Morphological variation and host range of two Ganoderma species from Papua New Guinea. Mycopathologia 158, 251-265. 
Pilotti CA, Sanderson FR, Aitken EAB. 2003 - Genetic structure of a population of Ganoderma boninense on oil palm. Plant Pathology, 52, 455-63.

Qi JJ, Ma RC, Chen XD, Lan J. 2003 - Analysis of genetic variation in Ganoderma lucidum after spaceflight. Adv Space Res, 31:1617-22.

Quanten E, 1997 - The polypores (Polyporaceae s.1.) of Papua New Guinea.OperaBot. Belgica 11, $1-352$.

Rakib MRM, Bong CFJ, Khairulmazmi A, Idris A.S. 2014 - Genetic and morphological diversity of Ganoderma species isolated from infected oil palms (Elaeis guineensis). Int. J. Agric. Biol., 16: 691-699.

Richter C, Wittstein K, Kirk MP, Stadler M, 2014 - An assessment of the taxonomy and chemotaxonomy of Ganoderma. Fungal Diversity, DOI 10.1007/s13225-014-0313-6.

Ryvarden L, Gilbertson RL. 1993 - European Polypores. Vol. 1. Abortiporus - Lindtneria. Oslo: Fungi flora. $387 \mathrm{p}$.

Ryvarden L, Johansen I. 1980 - A preliminary polypores flora of East Africa. Fungi flora, Oslo, pp $1-636$.

Ryvarden L. 2004 - Neotropical polypores Part 1. Synopsis Fungorum 19, 1-229.

Ryvarden L. 1985 - Type studies in the Polyporaceae. 17. Species described by W. A. Murrill. Mycotaxon 23:169-198.

Schwarze FWMR, Ferner D. 2003 - Ganoderma on trees-differentiation of species and studies of invasiveness. Arboricultural Journal, 25, 57-77.

Singer R. 1975 - The Agaricales in Modern taxonomy. 3rd ed. J. Cramer, Vaduz-Germany.

Singh SK, Doshi A, Pancholy A, Pathak R. 2013 - Biodiversity in wood-decay macro-fungi associated with declining arid zone trees of India as revealed by nuclear rDNA analysis. Eur J Plant Pathol.1-10.

Smith BJ, Sivasithamparam K. 2000a - Internal transcribed spacer ribosomal DNA sequence of five species of Ganoderma from Australia. Mycological Research, vol. 104, pp. 943 - 951.

Smith BJ, Sivasithamparam K. 2003 - Morphological studies of Ganoderma (Ganodermataceae) from the Australian and Pacific regions. Australasian Systematic Botany 16, 487-503.

Steyaert RL. 1972 - Species of Ganoderma and related genera mainly of the Bogor and Leiden Herbaria. Persoonia 7, 55-118.

Steyaert RL. 1978 - The concept and circumscription of Ganoderma tornatum. Trans. Brit. Mycol. Soc. $65,451-467$.

Steyaert RL. 1980 - Study of some Ganoderma species. Bull Jardin Bot Natl Belg 1980, 50:13586.

Stalpers JA. 1978 - Identification of wood-inhabiting fungi in pure culture. Studies in Mycology $16,1-248$.

Sun SJ, Gao W, Lin SQ, Zhu J.Xie BG, Lin ZB. 2006 - Analysis of genetic diversity in Ganoderma populations with a novel molecular marker SRAP. Appl Microbiol Biotechnol. 72,537-43.

Swofford DL. 2002 - PAUP*.Phylogenetic analysis using parsimony (*and other methods) Version 4.0b10.Sinauer Associates, Sunderland.

Szedlay G. 2002-is the widely used medicinal fungus the Ganoderma lucidum (fr.) karst. sensu stricto? Acta Microbiologica et Immunologica Hungarica 49 (2-3), pp. 235-243.

Szedlay GY, Jakucs E., Boka K, Boldizsar I. 1996 - Macro- and micro morphological characteristics of Ganoderma lucidum Karsten strains isolated in Hungary. - Annls hist.nat. Mus. natn. hung. 88: 57-68.

Tan BKH., Vanitha J. 2004 - Immunomodulatory and antimicrobial effects of some traditional Chinese medicinal herbs: a review. Curr Med Chem 11, 1423-1430.

Tamura K, Peterson D, Peterson N, Stecher G, Nei M, 2011- MEGA5: molecular evolutionary genetics analysis using maximum likelihood, evolutionary distance, and maximum parsimony methods. Mol Biol Evol 28, 2731-2739.

Teng SC. 1934 - Notes on Polyporaceae from China. Sinensia 5, 198-200. 
Wagner R, Mitchell DA, Sassaki GL., Amazonas MAL De A., Berovic M. 2003 - Current techniques for the cultivation of Ganoderma lucidum for the Production of biomass, ganoderic acid and polysaccharides.Food. Technol. Biotechnol. 41(4), 371-382.

Wang CH, Wang CH., Shen MH, Yan XY. 1996- Isolation and characterization of polysaccharides from Ganoderma lucidum.In Proc $2^{\text {nd }}$ IntConf Mush Biol Mush Prod (ed. D. J. Royse), pp.205-214. University Park, Pennsylvania.

Wang B, Hua J, 1991 - A Cultural Atlas of Some Ganoderma Cultures [M]. Taiwan: Publ. Food Indus. Res. and Develop. Ins! (FIRDI).

Wang DM, Wu SH, Li TH. 2009a - Two records of Ganoderma new to mainland China. Mycotaxon 108, 35-40.

Wang DM, Wu SH, Su CH, Peng JT, Shih YH. 2009b - Ganoderma multipileum, the correct name for 'G. lucidum' in tropical Asia. Bot Stud 50, 451-458.

Wang XC, Xi RJ, Li Y, Wang DM, Yao YJ. 2012 - The species identity of the widely cultivated Ganoderma, 'G. lucidum' (Ling-zhi), in China. PLoS ONE 7 -40857.

Wang XC, Yao YJ. 2009 - Taxonomic studies on 'Ganoderma lucidum 'in China. Abstracts of the 5th International Medicinal Mushroom Conference, Nantong, September 5-8, pp 104-106.

Wasser S.P. 2005 - Reishi or Ling Zhi (Ganoderma lucidum). In: Coates PM, Blackman MR, Cragg GM, Levine M, Moss J, White JD (eds) Encyclopedia of dietary supplements. Marcel Dekker, New York, pp 603-622.

Wasser SP. 2011 - Current findings, future trends, and unsolved problems in studies of medicinal mushrooms. Appl Microbiol Biotechnol 89, 1323-1332.

Wasser SP, Zmitrovich IV, Didukh MY, Spirin WA, Malysheva VF. 2006 - Morphological traits of Ganoderma lucidum complex highlighting G. tsugae var. jannieae: the current generalization.Gantner, Ruggell.

Wasser, SP. and Weis AL, 1999 a - General description of the most important medicinal higher basidiomycetes mushrooms. 1. Int J Med Mush 1, 351-370.

Wong LC, Bong CF.J, Idris AS, 2012 - Ganoderma species associated with basal stem rot disease of oil palm. Amer. J. Appl.Sci., 9, 879-885.

Wu SH, Dai YC, Hattori T. 2012 -Species clarification for the medicinally valuable 'sanghuang' mushroom. Bot Stud, 53, 135- 149.

Yang LZ, Feng B. 2013 - what is the Chinese "Lingzhi"? - A taxonomic mini-review, Mycology, An International Journal on Fungal Biology 4, 1, 1-4.

Yao YJ, Wang XC, Wang B. 2013- Epitypification of Ganoderma sichuanense J. D. Zhao and X. Q. Zhang (Ganodermataceae). Taxon 62, 1025-1031.

Ying JZ, Mao ZL, Ma QM, Zong LC, Wen HA. 1987 - Icons of medicinal fungi from China. Science Press, Beijing, pp 1-579, in Chinese.

Zhao JD. 1989 - The Ganodermataceae in China. Bibl Mycol. vol 132, pp. 1-176.

Zhao, JD, Xu, LW, Zhang, XQ. 1983 - Taxonomic studies on the family Ganodermataceae of China II. Acta Mycol. Sin. 2, 159-167.

Zhao JD, Zhang XQ. 2000 - Flora Fungorum Sinicorum. Vol. 8. Ganodermataceae. Science Press, Beijing.

Zheng L, Jia D, Fei X, Luo X, Yang Z. 2007 - An assessment of the genetic diversity within Ganoderma strains with AFLP and ITSPCR-RFLP. Microbiological Research 164, 312321.

Zhou LW, Cao Y, Wu SH, Vlasak J, Li WD, Li MJ, Dai. 2014 - Global diversity of the Ganoderma lucidum complex (Ganodermataceae, Polyporales) inferred from morphology and multilocus phylogeny. Photochemistry, http://dx.doi.org/10.1016/j.phytochem.2014.09.023 